\title{
The effect of replacing sand with aggregate from sanitary ceramic waste on the durability of stucco mortars
}

\author{
Beata Klimek ${ }^{1}$ (D) Jacek Szulej ${ }^{1}$ (D) Paweł Ogrodnik ${ }^{2}$ (D)
}

Received: 14 March 2020 / Accepted: 25 August 2020 / Published online: 8 September 2020

(c) The Author(s) 2020

\begin{abstract}
During processing and transport, the ceramic industry generates big amounts of waste. In order to limit the number of landfills and to minimise consequences of such waste that is clearly noxious for the environment, this industry remains under great pressure to find effective recycling methods for its waste and by-products. What is more, given the limited resources of traditional aggregate, energy savings and protection of the environment, the construction industry is seeking for new sources of aggregate. For this reason, ceramic waste is increasingly frequently used as coarse and fine aggregate, both in mortars and in concrete mixtures. The goal of studies presented in the paper was to analyse the impact of recycled ceramic aggregate on the frost and salt spray resistance of stucco mortar used in the construction industry. Mortar recipes also contained admixtures that modify properties of the mixture and of the hardened product, such as copolymer of vinyl acetate and methylcellulose with a hydrophobic admixture. Elementary testing was performed related to mechanical and physical parameters of mortars. Among others tests were carried out of compressive strength and flexural strength, a determination was made of density, open and total porosity, absorbability, resistance to salt spray corrosion and frost resistance after 25 freeze-thaw cycles of samples. Replacement of sand by recycled ceramic aggregate causes a change in physical parameters of mortars. It has a positive impact on strength parameters of mortars with concurrent reduction in absorbability and capillary action. Testing of mortar with the addition of ceramic aggregate has proved better frost resistance and resistance to salt crystallisation as compared to mortar to which sand had been added.
\end{abstract}

Jacek Szulej

j.szulej@pollub.pl

Beata Klimek

b.klimek@pollub.pl

Paweł Ogrodnik

pogrodnik@sgsp.edu.pl

1 Faculty of Civil Engineering and Architecture, Lublin

University of Technology, 40 Nadbystrzycka Str,

20-618 Lublin, Poland

2 The Main School of Fire Service, Institute of Security

Engineering, 52/54 Słowackiego Str., 01-629 Warsaw, Poland 


\section{Graphic abstract}

\section{New stucco mortar with ceramic aggregate}

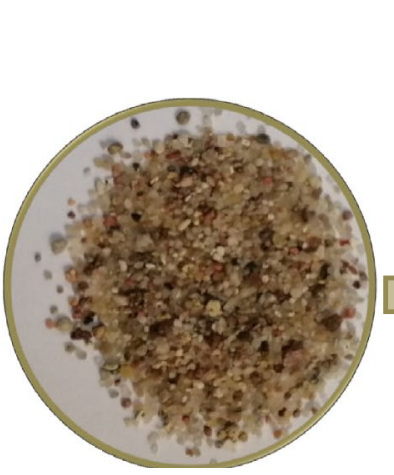

Sand and ceramic Aggregate used for production of mortar

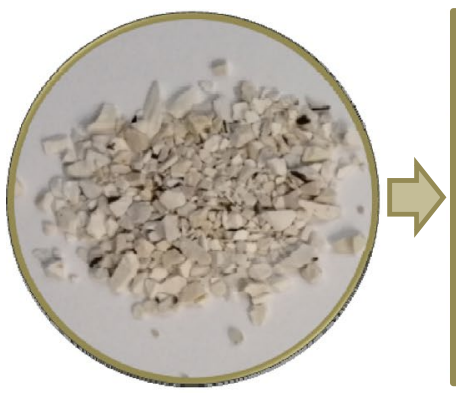

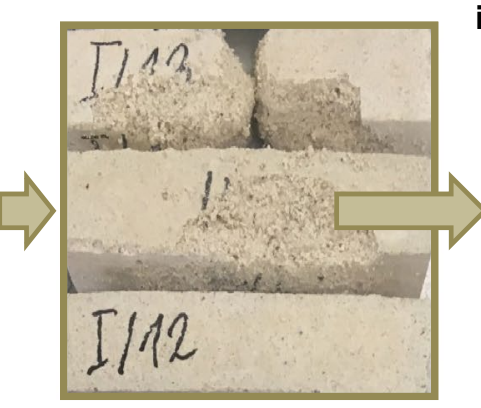

Conditions of samples after 25 freeze-thaw cycles

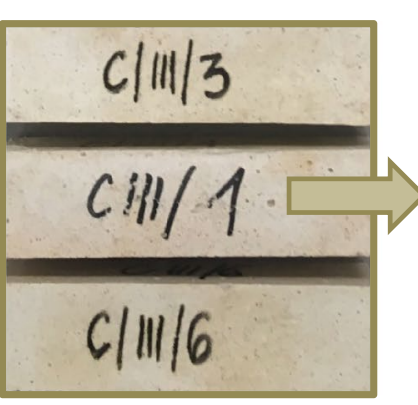

Mortar with sand quartz

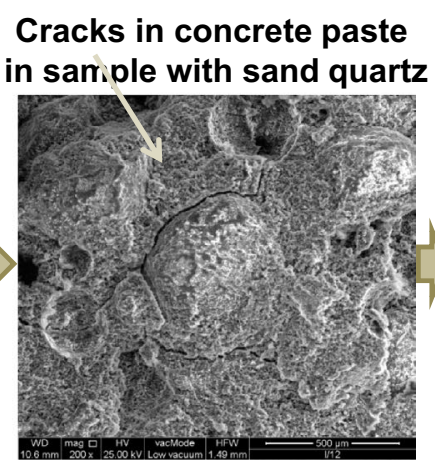

(Flexural Strength-MPa)

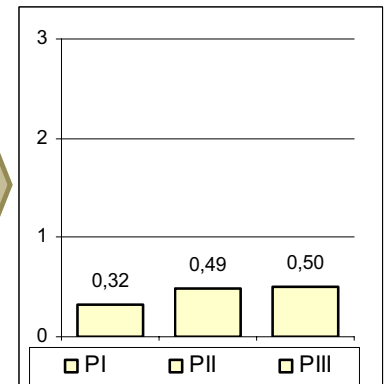

Mortar with ceramic aggregate (Flexural Strength-MPa) with ceramic aggregate

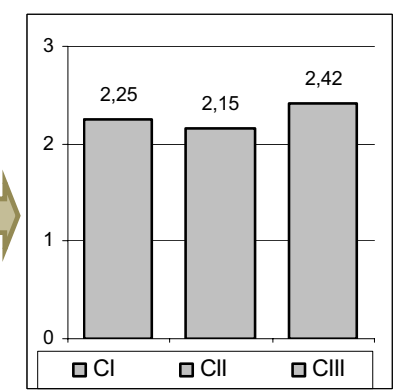

ceramic ware waste - alternative, low - cost, available and eco - efficient aggregate

Keywords Recycling $\cdot$ Ceramic ware waste $\cdot$ Stucco mortars

\section{Introduction}

The rapid increase in global population and the ever-developing economy cause the generation of large volumes of waste. Currently, the problem of waste is an environmental, social and economic issue. Currently, European countries place emphasis on the rational use of waste in an effort at limiting the need for traditional raw materials, reducing the environmental degradation by decreasing air and water pollution, reducing the energy consumption and creating new jobs. The European "Zero Waste" programme (European Commission 2014) assumes taking up measures aimed at transition onto a closed circle economy, which to a large extent has been based on the reuse and high quality of recycling, and much less on primary raw materials. Systems of closed circle economy retain the value added of products for a long time and allow elimination of wasting.
Waste generated during the production of sanitary ware requires over 4000 years to decompose in a natural process, which is not acceptable (Correia et al. 2006). The annual usage of aggregate in Poland equals to ca. 4-4.5 tonnes/persons and leads to the exploitation of 3 billion tonnes of non-renewable natural resources annually, at an average annual increase by 7\% (Uzunow 2014).

And so even a partial replacement of sand by aggregate containing ceramic waste would bring about considerable economic and ecological benefits, and this would contribute to reducing the number of landfills and less mining of natural sand.

Studies concerning the potential of various types of ceramic waste as active additives to materials basing on Portland cement have been published (Silva et al. 2008; Frías et al. 2008; Puertas et al. 2008). 
Most of them concern their influence on the properties of mortars and concretes in which they replace natural aggregates (Gonzalez-Corominas and Etxeberria 2014; Jimenez et al. 2013; Higashiyama et al. 2012, 2013).

Medina et al. have researched the properties of concretes with natural aggregate being partially substituted by 4/12.5 mm crushed sanitary ceramic (Medina et al. 2012a).

Studies show that the addition of up to $25 \%$ of sanitary ceramics increased the durability against bending and compressing. The authors also state that ceramic aggregate does not interfere with the hydration of cement. It was observed that the inner transitional zone between the cement grout and ceramic aggregate is more compact and less porous than the surface of natural aggregates. Furthermore, Medina et al. have examined the permeability of $\mathrm{O}_{2}$ and $\mathrm{CO}_{2}$ in concretes in which the aggregate had been substituted by 20 and $25 \%$ of $4 / 12.5 \mathrm{~mm}$ crushed ceramic ware waste (Medina et al. 2012b). The obtained test results showed that gas permeation, both in the reference and modified concrete, is at a comparable level, regardless of the content of ceramic filler. The depth of water penetration under pressure did not change either. In subsequent studies, scientists observed an increase in capillary pores in the concrete, which causes an increase in sorption (Medina et al. 2013).

Halicka et al. also researched concrete with the addition of ceramic ware waste (Halicka 2011; Halicka et al. 2013). They only replaced coarse-grained natural aggregate with ceramic aggregates from sanitary equipment. The ceramic aggregate used in this study had a grain size of $0 / 8 \mathrm{~mm}$. The obtained density values were similar to natural aggregate, 2.64 and 2.36, respectively, whereas the water absorption was slightly higher, $1.53 \%$. In the tests for compression, bending and resistance to high temperatures, the obtained values were higher for concretes with ceramic aggregate.

Research was also carried out on the use of a ceramic aggregate from sanitary waste in mortars. Farinha et al. (2015) found that the inclusion of ceramic powder obtained from sanitary waste into mortars resulted in the formation of stronger and less permeable mortars, which is in line with the findings of other researchers (Jackiewicz-Ręk et al. 2015). In both cases, in the tests performed, the mortars showed high bending and compressive strength. (Farinha et al. 2015) showed increases after 28 days were, respectively, $250 \%$ and $227 \%$ for bending and compressive strength compared to the reference mortar. Water permeability (capillarity) decreased in the first minutes by $30 \%$ compared to the reference mortar. However, the inclusion of this type of waste-in the form of a powder-deformed the mortars, which led to greater susceptibility to micro-cracking. As a result, after 90 days, the strength was reduced by about $48 \%$ and the compressive strength by about $36 \%$ (Farinha et al. 2015).
During research led by Lucas et al. (2016), it was noticed that aggregate obtained from recycling of sanitary equipment can be added to the mortars, replacing the natural aggregate with a fraction of equal size in $100 \%$ while maintaining good technical parameters.

The same researchers found that the sharp-edged shape of the ceramic aggregate resulted in the mortars having a higher bending strength. Subsequent studies also found a higher compressive strength (Higashiyama et al. 2012; Torkittikul and Chaipanich 2010). Lucas et al. (2016) observed that an increase in this strength after 90 days was almost $30 \%$ compared to the reference mortar, but the addition of recycled aggregate decreased the modulus of elasticity by $28 \%$ after 90 days, which indicates a better deformability compared to the reference mortar. According to the researchers, the main disadvantage of adding sanitary ceramics waste was the increase in water absorption. The use of sanitary ceramic waste instead of natural aggregate also increased the permeability of the mortar.

Including aggregates from sanitary equipment waste and replacing them with the original mortar components (natural aggregate or cement) may improve some mortar properties and thus improve their technical properties, including durability.

The porous structure of mortars, including stucco mortars, makes them exposed to factors that deteriorate their physical and mechanical properties (Karozou and Stefanidou 2018; Lugli et al. 2016). Basically, exterior mortars and stucco are prone to damage and cracking under the influence of chemicals such as chlorides and sulphates which are present in a polluted environment (Mohammadhosseini et al. 2014).

Most of the problems with superficial damage and fractures are related to concrete and mortar and are related to porosity (Medina et al. 2013; Mohammadhosseini and Tahir 2018).

A review of the literature and research on aggregates from recycling of sanitary appliances did not show that their use in stucco mortars was investigated. The research conducted by the authors analyses the possibilities of using aggregates from waste ceramics as a substitute for natural sand in stucco mortars. The physical and mechanical properties of the hardened mortars and their durability are assessed.

\section{Materials and methods}

\section{Materials}

The studies were based on six recipes of mixtures of plaster mortar. When choosing the proportions of ingredient and aggregate fractions use was made of a patented invention, namely plaster mortar based on Roman cement (Urban and 
Szeląg 2014). Mortar is primarily designated for repairs and renovation of old historical facades, plasters, castings, stuccos and other elements applied in building structures.

Each of the plasters, both the one containing quartz aggregates $(\mathrm{P})$ and ceramic aggregates obtained from recycling $(\mathrm{C})$, was represented in the studies by three compositions. The plaster mixtures have been differentiated by the additive of non-homogenous fractions of both aggregates. Figure 1 presents particular fractions of both aggregates designated for mortars. The devised mortar mixtures have been marked as follows, depending on their designation: (PI, CI) - coarse-grained plaster mortar for basic plastering and repairs of considerable losses to the elevations, (PII, CII) - fine-grained plaster mortar for finishing surfaces such as skim coat, (PIII, CIII) — average-grained plaster mortar used for cornice and stucco castings. Recipes of mortars containing ceramic aggregate (CI, CII, CIII) also contained admixtures improving the resistance of a hardened product to salt and low temperatures (copolymer of vinyl acetate

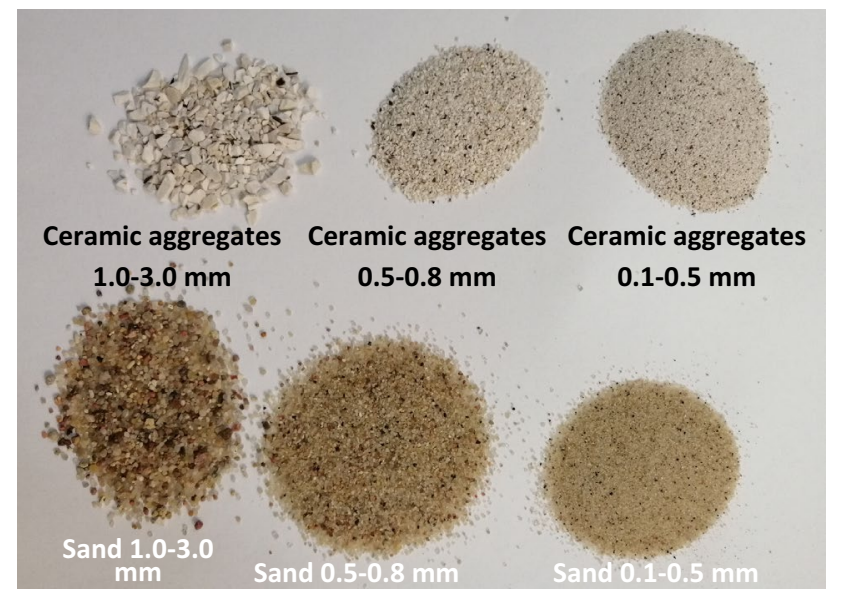

Fig. 1 View of ceramic aggregate and sand used for production of mortar and methylcellulose with a hydrophobic admixture). The percentage compositions of mixtures containing quartz and ceramic aggregate are presented in Table 1.

Below is a specific description of mortar ingredients.

The ingredients used to prepare the mortars are as follows:

- Portland cement-CEM I 52.5R, having the following specifications: a specific surface area of $4080 \mathrm{~cm}^{2} / \mathrm{g}$, beginning of binding $140 \mathrm{~min}$, end-170 min, compressive strength at 2 days- $-36.0 \mathrm{MPa}$ compressive strength at 28 days-56.6 MPa. Loss on ignition $2.1 \%$, whiteness $75 \%$, insoluble residue $0.43 \%, \mathrm{Cl}$ content of $0.06 \%, \mathrm{SO}_{3}$ content of $3.82 \%$, volume change of $0.8 \mathrm{~mm}$. Testing of Portland cement CEM I 52.5R was conducted in accordance with standard EN 197-1 (EN 197-1; Barnat-Hunek et al. 2017).

- Sand quartz - the chemical composition of sand, contents of ingredients (\%): $\mathrm{SiO}_{2}-93.4, \mathrm{Al}_{2} \mathrm{O}_{3}-2.3, \mathrm{CaO}-1.6$, $\mathrm{Fe}_{2} \mathrm{O}_{3}-1.3, \mathrm{~K}_{2} \mathrm{O}-1.1$, as well as trace amounts of $\mathrm{P}_{2} \mathrm{O}_{5}$, $\mathrm{TiO}_{2}, \mathrm{Cr}_{2} \mathrm{O}_{3}, \mathrm{MnO}, \mathrm{Co}_{3} \mathrm{O}_{4}, \mathrm{NiO}, \mathrm{CuO}, \mathrm{ZnO}, \mathrm{Rb}_{2} \mathrm{O}, \mathrm{SrO}$, $\mathrm{Y}_{2} \mathrm{O}_{3}, \mathrm{ZrO}_{2}, \mathrm{Ag}_{2} \mathrm{O}$ and $\mathrm{BaO}$. Density was determined by pycnometry, according to (PN-EN 1097-6:2013-11), which was found to be $2.66 \mathrm{~g} / \mathrm{cm}^{3}$, respectively. Bulk density in a loose state and compacted is $1.68 \mathrm{~g} / \mathrm{cm}^{3}$ and $1.87 \mathrm{~g} / \mathrm{cm}^{3}$ (Gil 2019).

- Ceramic aggregate - chemical composition of ceramic aggregate, contents of ingredients (\%): $\mathrm{SiO}_{2}-68.3 \%$, $\mathrm{Al}_{2} \mathrm{O}_{3}-22.5, \mathrm{~K}_{2} \mathrm{O}-4.3$ and $\mathrm{NiO}-3.3 \%$, as well as trace amounts of $\mathrm{Na}_{2} \mathrm{O}, \mathrm{MgO}, \mathrm{Fe}_{2} \mathrm{O}_{3}$. For ceramic aggregate with a grading of $0 \div 2 \mathrm{~mm}$, bulk density was determined according to (PN-EN 1097-6:2013-11), which amounted to $2.40 \mathrm{~g} / \mathrm{cm}^{3}$, and absorbability according to (PN-EN 932-2:2001), while the average absorbability is $1.98 \%$. The frost resistance test was implemented according to (PN-EN 1367-1:2007). Results of tests pointed to a mass loss equalling to $0.29 \%$, and consequently, it amounted
Table 1 Compositions of mortars (\%)

\begin{tabular}{|c|c|c|c|c|c|c|}
\hline \multirow[t]{2}{*}{ Material } & \multicolumn{3}{|c|}{ Series 1} & \multicolumn{3}{|c|}{ Series 2} \\
\hline & PI & PII & PIII & $\mathrm{CI}$ & CII & CIII \\
\hline Cement CEM I $52.5 \mathrm{R}$ & 35.5 & 45 & 53.5 & 35.5 & 45 & 53.5 \\
\hline Sand $0.1-0.5 \mathrm{~mm}$ & 33.5 & 45 & 22.5 & - & - & - \\
\hline Sand $0.5-0.8 \mathrm{~mm}$ & 13 & - & 9 & - & - & - \\
\hline Sand $1.0-3.0 \mathrm{~mm}$ & 8 & - & 3.5 & - & - & - \\
\hline Ceramic aggregate $0.1-0.5 \mathrm{~mm}$ & - & - & - & 33.5 & 45 & 22.5 \\
\hline Ceramic aggregate $0.5-0.8 \mathrm{~mm}$ & - & - & - & 13 & - & 9 \\
\hline Ceramic aggregate $1.0-3.0 \mathrm{~mm}$ & - & - & - & 8 & - & 3.5 \\
\hline Methylcellulose & 0 & 0 & 0 & 0.15 & 0.15 & 0.15 \\
\hline Copolymer of vinyl acetate-ethylene & 0 & 0 & 0 & 0.9 & 0.9 & 0.9 \\
\hline Water & 25 & 25 & 25 & 25 & 25 & 25 \\
\hline
\end{tabular}

Composition of mortar containing sand and ceramic aggregate for recycling 
to $\leq 1 \%$, which consistently with requirements of (PN-EN 1367-1:2007) allows the categorisation of aggregate to category $F_{1}$.

- Retentor, methylcellulose hydroxide - addition of $0.15 \%$ in all mixtures. Utilising this addition enables obtaining higher performance of the mortar's properties. One of the most important qualities of those mortars related to the addition of methylcellulose is increasing water retention in the mortar, which assures appropriate conditions for binding and setting of the binder.

- Ethylene-vinyl acetate copolymer-a $0.9 \%$ additive as a plastifying and strengthening admixture. Adding the polymer enhances several performance characteristics of mortar and concrete, increases the workability as well as water retention in the mortar and slows down the time of evaporation, considerably enhances adherence to all building substrate types and also increases the mixtures elasticity.

For the needs of the test, a set of cubic samples were prepared from the above-mentioned mortars with dimensions of $40 \times 40 \times 160 \mathrm{~mm}$ pursuant to EN 196-7:2008 (EN 196$7: 2008)$. The samples were removed from the moulds after $24 \mathrm{~h}$, marked on the upper surface, and placed in a climatic chamber for 21 days at a temperature of $23.5^{\circ} \mathrm{C}$ and humidity of $73.5 \%$, where they remained until the commencement of testing.

\section{Methods}

\section{Physical properties of mortars}

The testing of (apparent) bulk density, the volume of open pores as well as the open porosity of mortars was performed pursuant to the standard EN 1936:2010. The determination of total density was carried out by pycnometry described in the standard EN 1936:2010. Ambient temperature amounted to ca. $20^{\circ} \mathrm{C}$

Absorbability of mortar containing sand and ceramic aggregate was determined pursuant to the standard PN-B04500:1985. For needs of the testing samples were produced having dimensions of $40 \times 40 \times 160 \mathrm{~mm}-4$ samples each of PI, PII, PIII and 4 samples of CI, CII, CIII. Prior to commencing the testing, the samples were dried to constant mass, and the measurement of absorbability by weight was performed after 14 days (Krzywoblocka-Laurów 2000).

A direct method according to EN 12012:2007 was used to determine frost resistance. Six samples with the dimensions $40 \times 40 \times 160 \mathrm{~mm}$ were used for each type of tested mortar. First, the samples were frozen at the temperature of $-18 \pm 2{ }^{\circ} \mathrm{C}$ for at least $4 \mathrm{~h}$ and subsequently thawed in water at the temperature of $18 \pm 2{ }^{\circ} \mathrm{C}$, for a length of time ranging between 2 and $4 \mathrm{~h}$. A single experiment cycle is an entire process of freezing and thawing, and 25 cycles were carried out in total. Upon completing the last, $25^{\text {th }}$ cycle, the samples were dried to a fixed weight. They were then weighed a second time to measure the weight lost after determining their frost resistance.

EN 12370:2001 was utilised in order to test the resistance to salt crystallisation; 6 samples of each type of mortar were used in conducting the experiment, each with the dimensions of $40 \times 40 \times 160 \mathrm{~mm}$. The samples were dried, weighed and then submerged in a $14 \%$ solution of sodium sulphate decahydrate for $2 \mathrm{~h}$. Afterwards, the temperature used to dry the samples was in a state of progressive increase until it reached $105^{\circ} \mathrm{C}$, which was reached after $10 \mathrm{~h}$ of the experiment. Moreover, during the beginning phase of drying, a high relative moisture will be maintained. The samples were saturated with sodium sulphate a second time after drying, and the cycle was repeated 15 times. The samples were stored in water for $24 \mathrm{~h}$ and then washed with water, dried and weighed. The results of the experiment are displayed in the form of percentage values as a relative difference of mass as compared to the initial mass of the sample and the number of cycles till destruction, meaning the lack of resistance to salt crystallisation.

Scanning electron microscopy (SEM) was used to determine the morphology of mortars (PII, PIII, CII and CIII), their porous structure and the interfacial transition zone between the aggregate and paste. The observations were made using the FEG Quanta 250 microscope.

\section{Mechanical properties of mortars}

The EN 1015-11 standard using three and six samples, respectively, was used to determine the flexural and compressive strength. The former was determined by three-point loading of hardened mortar beams until the point of their destruction. The samples used to determine the compressive strength were obtained from those used in the previous set estimation of flexural strength.

\section{Results and discussions}

\section{Physical properties}

The physical properties of mortar after hardening adopted for the examination are shown in Table 2.

The conducted testing allows the presumption that samples PI, PII and PIII have a comparable value of apparent density and porosity. A similar dependence also takes place between samples CI CII and CIII.

Mortars with the addition of quartz sand are characterised by high open porosity, the value of which is within the 
range of $28.08-29.78 \%$, with a slightly lower open porosity recorded for mortars that contained recycled aggregate within the range of 26.66-28.63\%.

Mortars with the addition of quartz sand are characterised by a very high water absorption coefficient, the value of which ranges between 21.2 and $22.8 \%$, while the water absorption index for plasters containing ceramic aggregate is slightly lower and remains within the range of $18-20 \%$.

\section{Strength properties}

Table 3 presents the strength properties of the plasters used in the research. Weight loss after 25 cycles of freezing-thawing refers to the plasters' frost resistance, whereas the resistance to salt crystallisation was defined as the loss of weight after 15 cycles of testing.

The average compressive strength before and after 25 cycles of freezing and thawing is presented in Fig. 2. The highest average flexural strength $\left(2.51 \mathrm{~N} / \mathrm{mm}^{2}\right)$ was recorded for the CIII sample series which contained ceramic aggregate. Similar samples of PIII with quartz aggregate obtained a value lower by $31 \%\left(1.74 \mathrm{~N} / \mathrm{mm}^{2}\right)$. The same samples after 25 freezing cycles still had the highest values for $\mathrm{CIII} / \mathrm{F}$ $\left(2.42 \mathrm{~N} / \mathrm{mm}^{2}\right)$, while samples of PIII/F proved to have a decline in flexural strength at the level of $79 \%$. Similar dependencies of the average strengths are visible for samples containing ceramic and quartz aggregate.

Samples for needs of testing the compressive strength were obtained as a result of flexural strength determination performed earlier on. The average flexural strength before and after 25 freeze-thaw cycles is presented in Fig. 3. The highest average strength was recorded for the sample series CIII (7.06 N/mm ${ }^{2}$ ) and was higher as compared to the sample series PIII by $30 \%$. The same samples after 25 freezing cycles still had the highest values for CIII/F $\left(6.55 \mathrm{~N} / \mathrm{mm}^{2}\right)$,
Table 2 Physical properties of plasters

Table 3 Mechanical properties of plasters

Fig. 2 Average flexural strength of mortars (PI, PII, PIII, CI, $\mathrm{CII}$ and CIII). Average flexural strength of mortars, after 25 freeze-thaw cycles (PI/F, PII/F, $\mathrm{PIII} / \mathrm{F}, \mathrm{CI} / \mathrm{F}, \mathrm{CII} / \mathrm{F}$ and $\mathrm{CIII} / \mathrm{F}$ )

\begin{tabular}{|c|c|c|c|c|c|c|}
\hline & \multicolumn{3}{|c|}{ Series 1} & \multicolumn{3}{|c|}{ Series 2} \\
\hline & PI & PII & PIII & $\mathrm{CI}$ & $\mathrm{CII}$ & CIII \\
\hline Apparent density $\rho_{\mathrm{a}}\left(\mathrm{kg} / \mathrm{m}^{3}\right)$ & 1.38 & 1.35 & 1.42 & 1.46 & 1.41 & 1.49 \\
\hline Density $\rho\left(\mathrm{kg} / \mathrm{m}^{3}\right)$ & 2.38 & 2.36 & 2.39 & 2.37 & 2.34 & 2.42 \\
\hline Total porosity $P(\%)$ & 41.85 & 43.31 & 40.59 & 38.25 & 38.69 & 38.07 \\
\hline Open porosity $P_{\mathrm{o}}(\%)$ & 29.46 & 29.78 & 28.08 & 27.42 & 28.63 & 26.66 \\
\hline Absorptivity (\%) & 22.3 & 22.8 & 21.2 & 19.00 & 20.00 & 18.00 \\
\hline
\end{tabular}

\begin{tabular}{|c|c|c|c|c|c|c|}
\hline & \multicolumn{3}{|c|}{ Series 1} & \multicolumn{3}{|c|}{ Series 2} \\
\hline & PI & PII & PIII & CI & $\mathrm{CII}$ & CIII \\
\hline Flexural strength $\beta_{\mathrm{bz}}\left(\mathrm{N} / \mathrm{mm}^{2}\right)$ & 1.455 & 1.950 & 1.736 & 2.315 & 2.248 & 2.509 \\
\hline Compressive strength $\beta_{\mathrm{d}}\left(\mathrm{N} / \mathrm{mm}^{2}\right)$ & 4.169 & 4.365 & 4.919 & 6.792 & 5.408 & 7.062 \\
\hline$\beta_{\mathrm{d}} / \beta_{\mathrm{bz}}$ ratio & 2.87 & 2.24 & 2.83 & 2.93 & 2.41 & 2.81 \\
\hline Flexural strength $\beta_{\mathrm{bz}}\left(\mathrm{N} / \mathrm{mm}^{2}\right)$ after frost & 0.320 & 0.485 & 0.500 & 2.246 & 2.147 & 2.418 \\
\hline Compressive strength $\beta_{\mathrm{d}}\left(\mathrm{N} / \mathrm{mm}^{2}\right)$ after frost & 1.093 & 1.555 & 1.666 & 5.297 & 5.204 & 6.545 \\
\hline$\beta_{\mathrm{d}} / \beta_{\mathrm{bz}}$ ratio & 3.42 & 3.21 & 3.33 & 2.36 & 2.41 & 2.71 \\
\hline Frost resistance (-) mass loss (\%) & 0.80 & 0.50 & 0.40 & 0.30 & 0.20 & 0.10 \\
\hline Salt crystallisation (-) mass difference (\%) & 0.50 & 0.30 & 0.20 & 0.25 & 0.15 & 0.10 \\
\hline
\end{tabular}

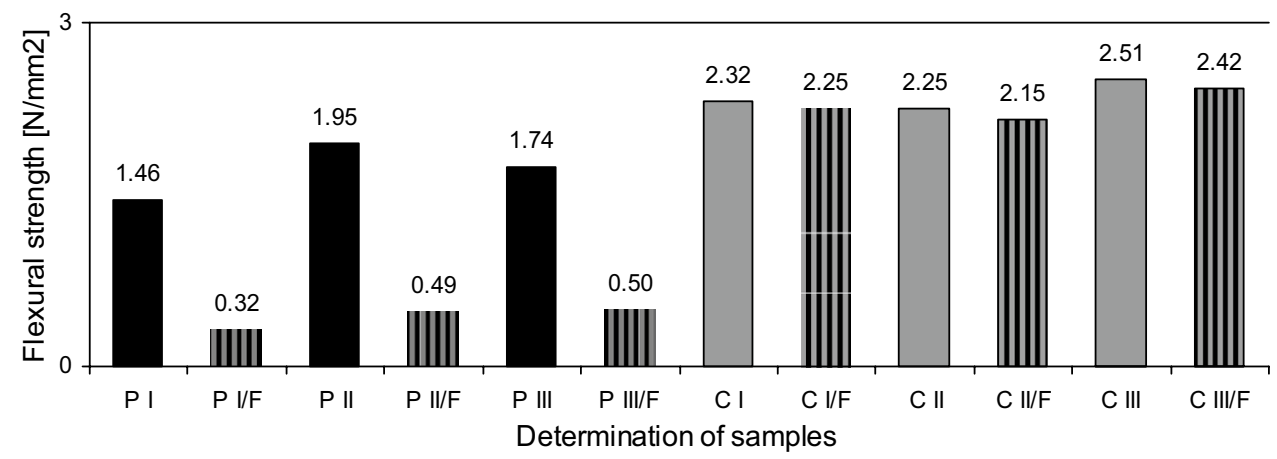


Fig. 3 Average compressive strength of mortars (PI, PII, PIII, CI, CII and CIII). Average compressive strength, after 25 freeze-thaw cycles (PI/F, PII/F, $\mathrm{PIII} / \mathrm{F}, \mathrm{CI} / \mathrm{F}, \mathrm{CII} / \mathrm{F}$ and $\mathrm{CIII} / \mathrm{F}$ )

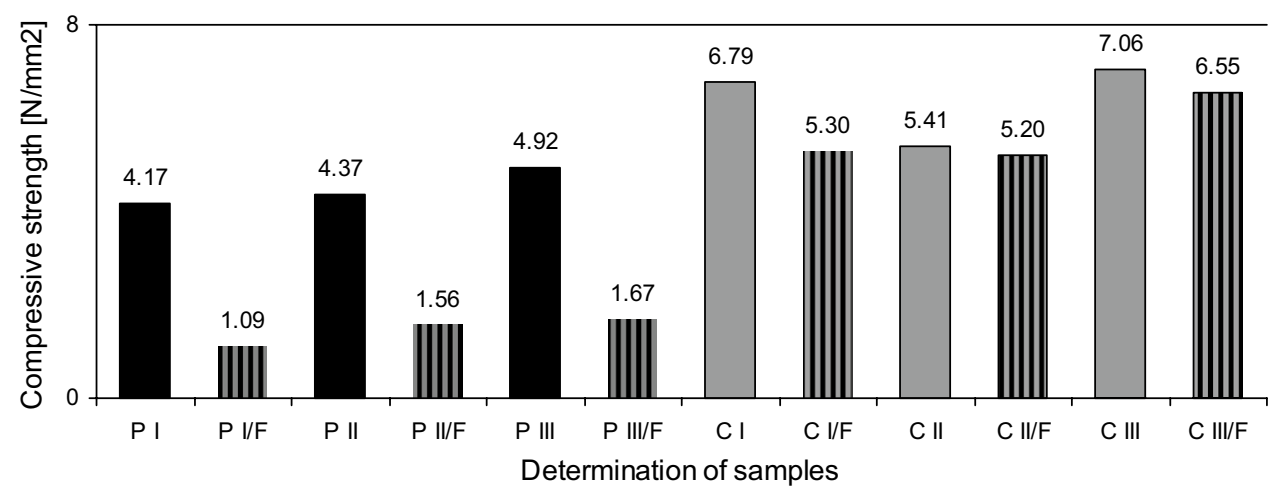

while samples PIII/F have pointed to a decline of compressive strength at the level of $75 \%$.

This improvement in the strength of mortars with ceramic aggregate can be attributed to the pozzolanic reaction taking place between the reactive silicon oxide ( $\mathrm{SiO} 2)$, which is present in a high percentage in the ceramic powder, and hydration products such as calcium hydroxide $\left(\mathrm{Ca}(\mathrm{OH})_{2}\right)$. Therefore, chemical reactions between $\mathrm{SiO}_{2}$ and $\mathrm{Ca}(\mathrm{OH})_{2}$ result in the formation of additional $\mathrm{CSH}$ gels in mortars with ceramics (Siddique et al. 2017). By developing additional C-S-H gels, the reduced porosity is reduced and, consequently, we obtain higher durability (Mohammadhosseini and Yatim 2017). Similar observations were made by Matias et al. (2012a, b, 2014) who found that partial replacement of cement with ceramic aggregate significantly improved the compressive strength of both the mortar and concrete.

\section{Resistance to salt crystallisation}

All samples used in the testing were found to be resistant to salt crystallisation. Samples of mortars containing both sand and ceramic aggregate during 15 testing cycles were not destroyed. The average percentage pf mass loss of mortars after tests of resistance to salt crystallisation is presented in Fig. 4.
Mortars denoted as PI and PII and PIII are characterised by a mass loss equalling to 0.50 and $0.30 \%$ and $0.20 \%$, respectively. As regards samples containing ceramic aggregate, the mass loss was found to have lower values within the range of $d 0.25-0.10 \%$. The smallest mass loss was recorded for mortar CIII.

Tests of crystallisation were supplemented by the visual inspection of samples according to the below scale (EN 12370:2001):

0-no damage to the sample,

1-very slight damage, no disintegration,

$\mathbf{2}$-damage to the sample consisting of one or several small cracks,

3 -damage to the sample consisting of one or several small cracks and delamination of small sample fragments,

4 - large cracks of the sample or its breaking,

5-total sample destruction, falling apart of the sample.

The surface of the majority of samples was found to be either undamaged or very slightly damaged as shown in Fig. 5a, b, which conforms to grade 0 and 1 in the above specified scale.
Fig. 4 Average percentage of mass loss of mortars after testing related to resistance to salt crystallisation

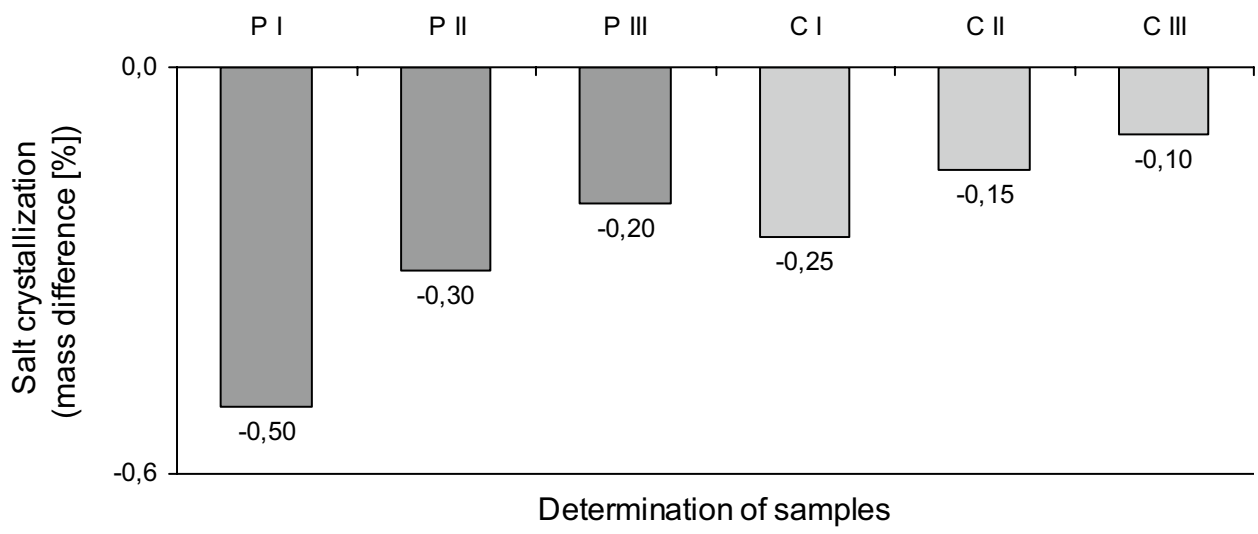


Fig. 5 a View of samples immersed in salt solution. b Samples of mortars after 15 cycles of salt crystallisation
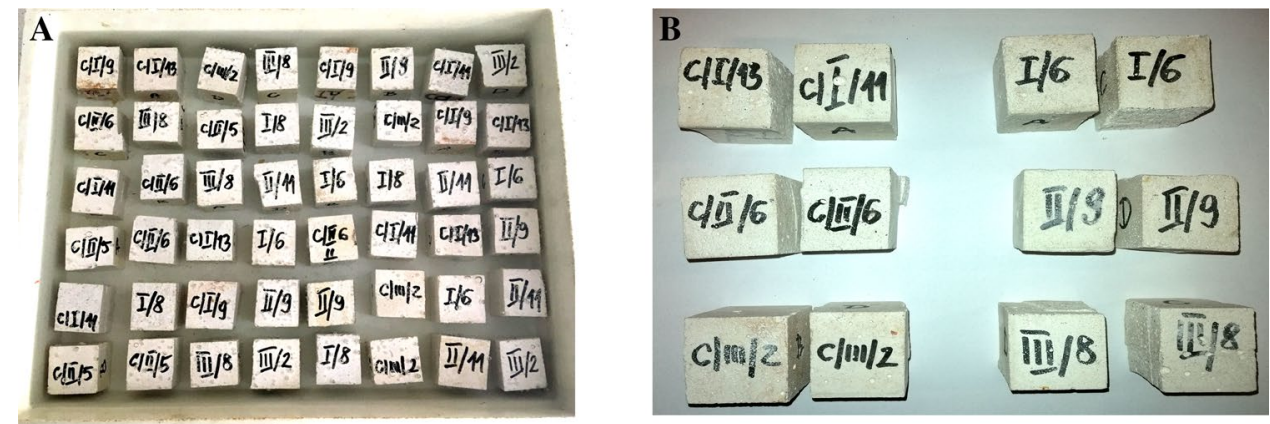
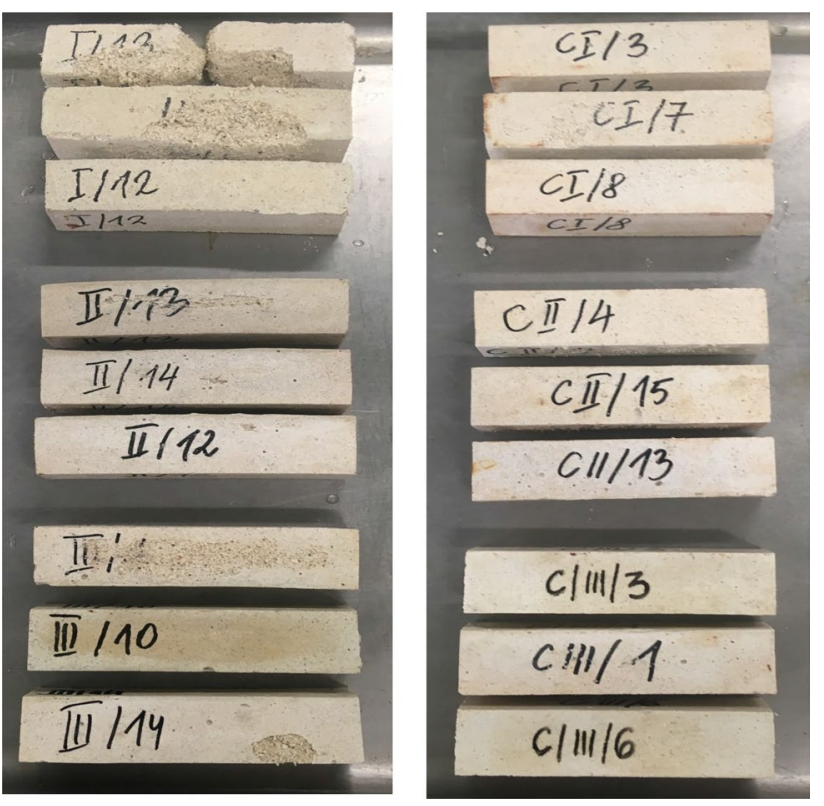

Fig. 6 Preservation conditions of PI/F, PII/F, PIII/F, CI/F, CII/F and $\mathrm{CIII} / \mathrm{F}$, samples after 25 freeze-thaw cycles and drying to the dry mass

\section{Frost resistance}

During testing of the mortar frost resistance, on the samples the first visible negative impact of variable temperatures consisting of cracking has appeared on sample PI/F after 11 cycles of testing.

After 21 cycles of testing observe were high mass losses of samples PI/F, while samples PII/F were found to have only slight mass losses and insignificant cracking. Figure 6 presents conditions of the tested mortars samples after 25 cycles of freezing-thawing and drying to the dry mass.

The mean percentage mass loss of mortars is presented in Fig. 7.

An analysis of the results of the tests conducted after 25 cycles has shown that the lowest resistance was recorded for samples with quartz aggregate. The lowest resistance was recorded for samples $\mathrm{PI} / \mathrm{F}$, which were characterised by the biggest mass loss at the level of $0.8 \%$. Samples CI/F, CII/F and $\mathrm{CIII} / \mathrm{F}$ containing ceramic aggregate were found to be resistant to variable temperatures. No major mass losses, scratches or cracking has been ascertained. The smallest mass reduction of $0.1 \%$ has been ascertained for samples C III/F.

Most of the factors causing degradation and damage are related to moisture and capillary rise, which helps the water to penetrate the pores of the mortar. These factors cause the
Fig. 7 Mean percentage mass reduction after frost resistance observations

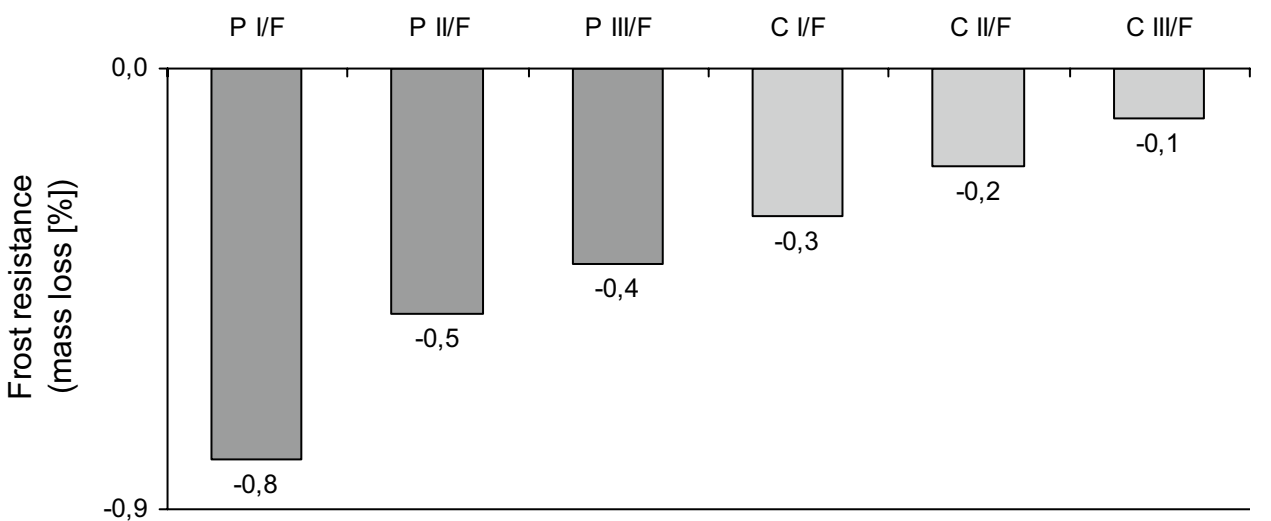

Determination of samples 
deterioration of mortars; among others, they reduce frost resistance and contribute to the penetration of water-soluble salts into the mortars (Stratoura et al. 2018).

There are several methods known to improve the durability of the mortar and protect it against the negative effects of harmful factors. One is to provide a dense microstructure using materials and involves a gradual distribution of aggregate particle size to reduce the ingress of chemicals and water causing degradation. This method can significantly improve the durability and strength of concrete and mortar exposed to an aggressive environment, as stated by Higashiyama et al. (2012).

As shown in Fig. 8, after 25 freeze-thaw cycles, samples $(\mathrm{PI} / \mathrm{F}, \mathrm{PIII} / \mathrm{F})$ with the addition of sand were found to have the same degree of destruction on the aggregate surface. The main types of damage comprised the following: (a) breaking away of aggregate, (b) destruction, degradation, impairment of the surface of coarse aggregate and (c) delamination in the zone between aggregate and binder. On the other hand, as shown in Fig. 8 samples $(\mathrm{CI} / \mathrm{F}, \mathrm{CIII} / \mathrm{F})$ containing ceramic aggregate were not found to have any traces of surface destruction.

Microstructural damage caused by freeze-thaw processes may be divided into two main groups: debonding in the zone between aggregate and binder and the binder zone. Figures 8 and 9 indicate that after 25 freeze-thaw cycles, cracking and degradation were found to be bigger than in mortars with an addition of natural aggregate than in similar mortars containing an additive of aggregate from recycling.

Figures 8 and 9 present typical micro-cracks for mortars. The higher level of detail in Fig. 9 also allows ascertaining that the cracks are wider and that there are more of them in mortars that contain quartz aggregate $(\mathrm{PI} / \mathrm{F}, \mathrm{PIII} / \mathrm{F})$ which
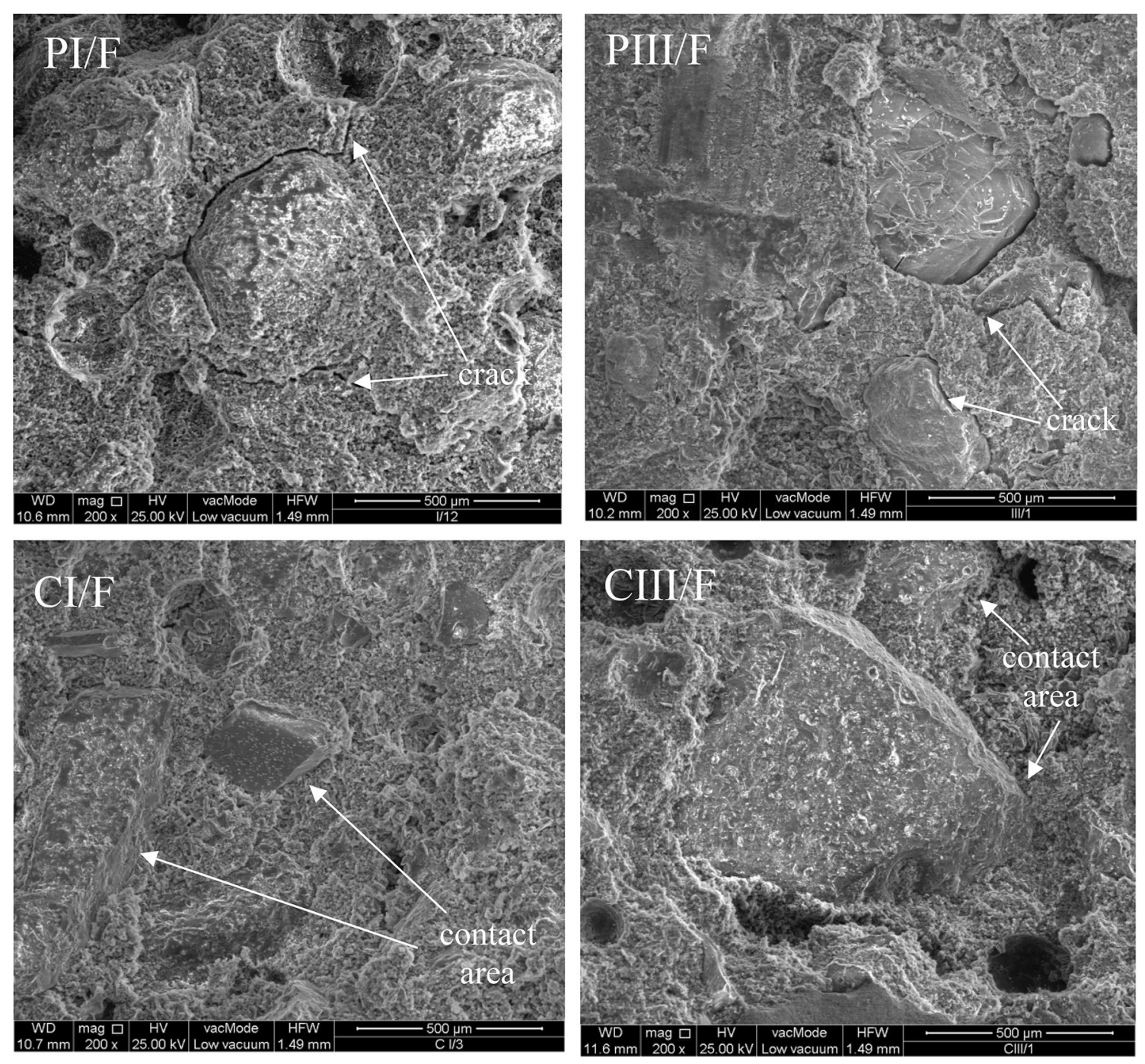

Fig. 8 Cracks in concrete paste in samples P I/F, PIII/F contact surface in samples C I/F, C III/F 

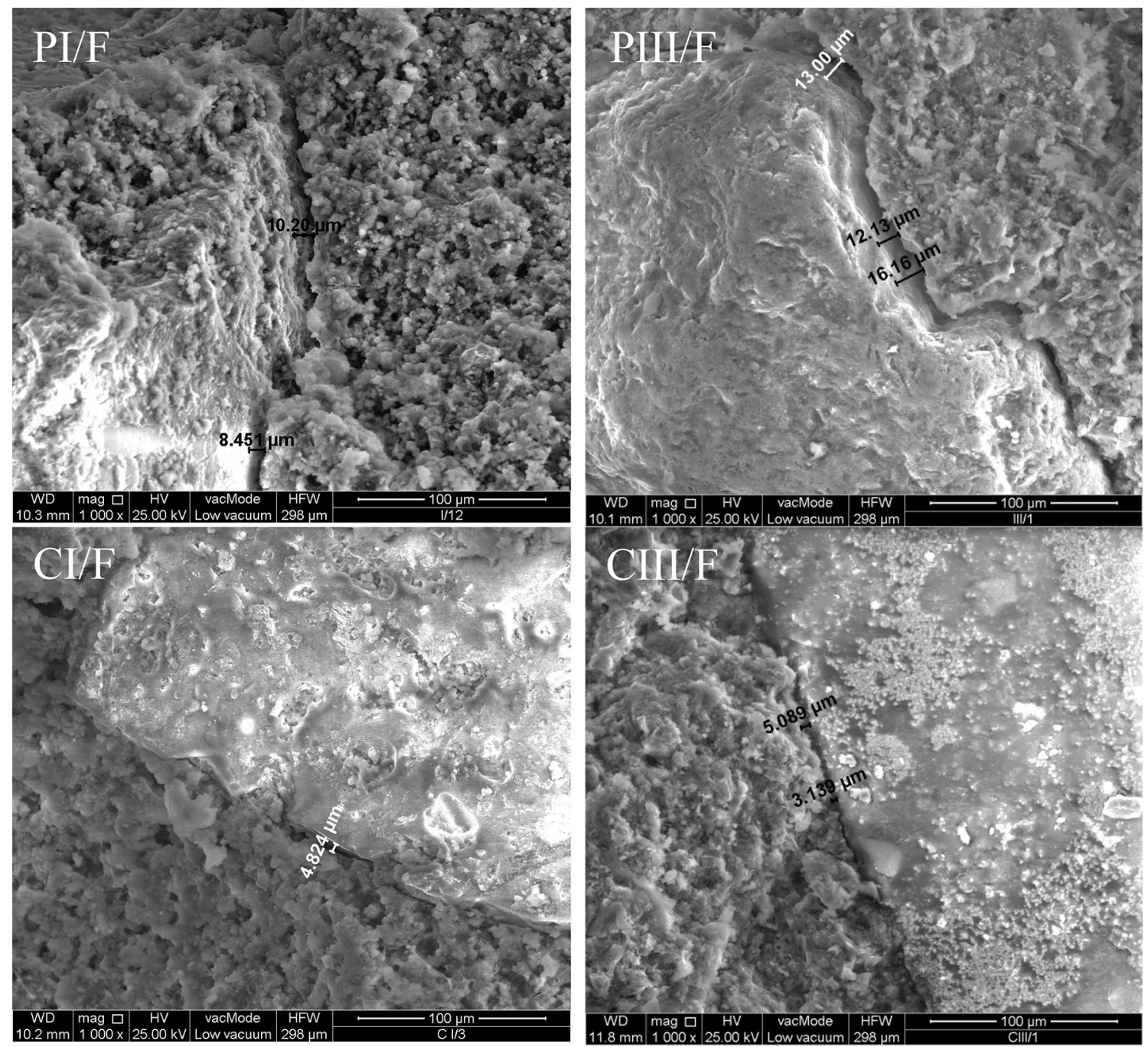

Fig. 9 Micro-crack distribution at the aggregate/paste interface in samples PI/F, PIII/F, CI/F and CIII/F

tend to spread in a perpendicular way to the outside from the aggregate surface.

The CI/F and CIII/F mortars are more compact with a small amount of small pores and show no cracks or scratches, which is reflected in the physical properties tests. The structure of the PI/F and PIII/F mortars shows a significant amount of medium and large pores (Fig. 10).

Table 4 provides the average and maximum widths of cracks in mortars, on the point of contact of the aggregate and binder. The values given in the table point to a significant difference as to the average and maximum widths of micro-cracks for both types of aggregate. Minimum and maximum micro-cracks have been recorded for sample CIII/F (min. $3.13 \mu \mathrm{m} / \max .5 .08 \mu \mathrm{m}$ ) which was smaller than in samples containing quartz sand PI/F (min. $7.37 \mu \mathrm{m} / \mathrm{max}$. $13.47 \mu \mathrm{m}$ ) and PIII/F (min. $6.67 \mu \mathrm{m} / \mathrm{max} .10 .45 \mu \mathrm{m}$ ).

Samples CI/F and CIII/F samples have a smaller number of pores in the range $(2.3-8.7 \mu \mathrm{m})$ and micro-cracks in the structure than PI/F and PIII/F of the mortar, which is also confirmed by tests on physical properties. These mortars are characterised by the lowest absorbency, open porosity and weight loss after frost resistance and salt crystallisation tests. The structure of the PI/F and PIII/F mortars shows a significant amount of medium and large pores in the range $(3.7-28.7 \mu \mathrm{m})$ which is associated with higher absorbency and greater weight loss after durability tests.

It was also observed that the voids in the mortar with ceramic aggregate were relatively smaller due to the development of additional CSH gels in the reaction between $\mathrm{SiO}_{2}$ with the ceramic powder and calcium hydroxide (as a result of cement hydration). Moreover, the ceramic powder not only generated more CSH gels but also acted as a filler that reduced the number and size of the pores in the mortar (Siddique et al. 2018; Huseien et al. 2017). In addition, fine ceramic aggregate also ensured a lower permeability of the 

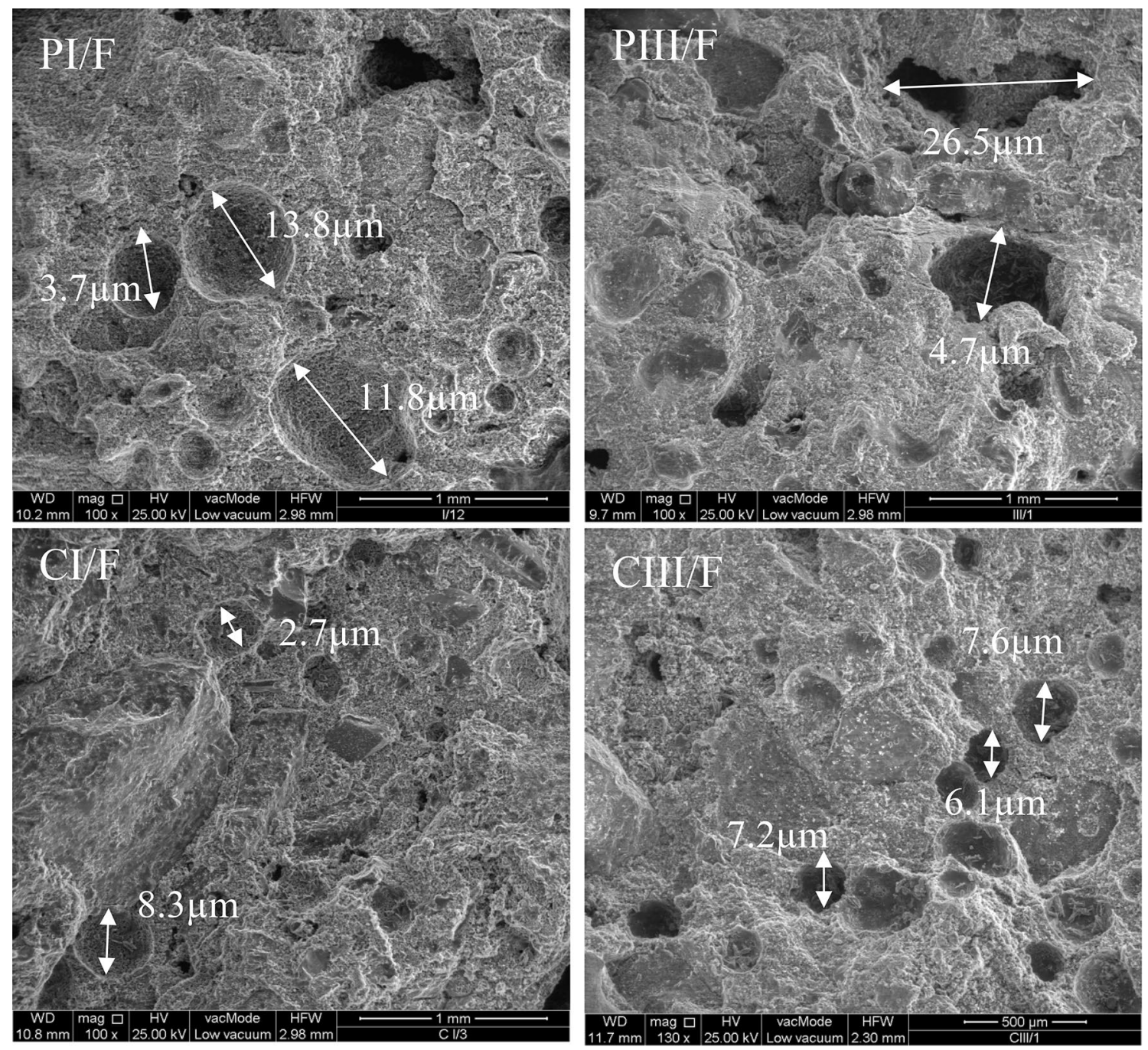

Fig. 10 Fracture surfaces of samples and pores in mortars with quartz and recycled aggregate

mortar, compared to natural sand (Higashiyama et al. 2012). Frozen water expands, causing severe damage to the mortar. In very absorbent materials, more water crystallises in the pores. The used modifying additives reduce the porosity of the cement mortar and seal it. In turn, an increase in the degree of hydration reduces the porosity of the cement

Table 4 Minimum and maximum micro-cracks in mortar on point of contact of aggregate and binder

\begin{tabular}{lll}
\hline Mortar & Minimum micro-crack $(\mu \mathrm{m})$ & $\begin{array}{l}\text { Maximum } \\
\text { micro-crack } \\
(\mu \mathrm{m})\end{array}$ \\
\hline $\mathrm{PI} / \mathrm{F}$ & 7.37 & 13.47 \\
$\mathrm{PIII} / \mathrm{F}$ & 6.67 & 10.45 \\
$\mathrm{CI} / \mathrm{F}$ & 3.55 & 8.45 \\
$\mathrm{CIII} / \mathrm{F}$ & 3.13 & 5.08 \\
\hline
\end{tabular}

mortar which made it difficult for water to penetrate the pores, and thus, the amount of frozen water was reduced. All mortars with additives and ceramic aggregate proved frost resistant and had little weight loss after cyclic freeze-thaw tests and salt crystallisation tests.

\section{Conclusions}

The above-discussed results allow drawing of the following conclusions.

- A small impact was observed of the type of aggregate on physical properties of hardened mortar. The density and porosity of mortar containing ceramic aggregate are comparable to those with quartz aggregate. As regards 
mortars with ceramic aggregate, the water absorption index was found to decrease.

- Results of strength tests before and after 25 freeze-thaw cycles clearly speak to the favour of ceramic aggregate. Mean tensile strength values for the group of mortars with ceramic aggregate equalled to $2.36 \mathrm{~N} / \mathrm{mm}^{2}$ and for mortars containing sand $-1.72 \mathrm{~N} / \mathrm{mm}^{2}$. Average values of compressive strength for the group of mortars based on ceramic aggregate amounted to $6.42 \mathrm{~N} / \mathrm{mm}^{2}$ while mortar containing sand- $4.49 \mathrm{~N} / \mathrm{mm}^{2}$. After 25 freeze-thaw cycles, mortars containing ceramic sanitary ware have obtained higher strength values. Mean tensile strength values for the group of mortars containing ceramic aggregate amounted to $2.27 \mathrm{~N} / \mathrm{mm}^{2}$ and mortar with sand $0.44 \mathrm{~N} / \mathrm{mm}^{2}$. Mean compressive strength values for the group of mortars with ceramic aggregate came up to $5.68 \mathrm{~N} / \mathrm{mm}^{2}$ and mortars containing sand$1.44 \mathrm{~N} / \mathrm{mm}^{2}$.

- Aggregate from sanitary ceramic ware is more resistant to temperature changes than natural quartz aggregate. Average values of mass loss after 25 freeze-thaw cycles for the group of mortars with ceramic aggregate equalled to $0.17 \%$, and for mortars with sand this value was $0.33 \%$.

- Given the occurrence of cracking and scratches, after 25 freeze-thaw cycles, mortars containing ceramic aggregate were found to have better resistance properties. The average width for the group of mortars $-5.41 \mu \mathrm{m}$, for mortars based on quartz sand was twofold higher and equalled to $10.41 \mu \mathrm{m}$. All mortars, regardless of the type of aggregate, were found to be resistant to salt crystallisation. The mean mass loss for the group of mortars containing ceramic materials was $0.2 \%$ and for quartzbased aggregate $0.57 \%$.

- Pursuant to results obtained in our studies, it has been found that mortar containing ceramic aggregate obtained from recycling may be used as stucco mortars, as they meet requirements posed to materials exposed to humidity, frost changes and salt crystallisation on elevations. Nevertheless, more extensive strength tests are required in further works.

- Technical, economic and environmental benefits related to potential replacement of natural aggregate by sanitary ware from recycling open possibilities of a sustainable development of the construction sector.

\section{Compliance with ethical standards}

Conflict of interest The authors declare that they have no conflict of interest.
Open Access This article is licensed under a Creative Commons Attribution 4.0 International License, which permits use, sharing, adaptation, distribution and reproduction in any medium or format, as long as you give appropriate credit to the original author(s) and the source, provide a link to the Creative Commons licence, and indicate if changes were made. The images or other third party material in this article are included in the article's Creative Commons licence, unless indicated otherwise in a credit line to the material. If material is not included in the article's Creative Commons licence and your intended use is not permitted by statutory regulation or exceeds the permitted use, you will need to obtain permission directly from the copyright holder. To view a copy of this licence, visit http://creativecommons.org/licenses/by/4.0/.

\section{References}

Barnat-Hunek D, Siddique R, Klimek B, Franus M (2017) The use of zeolite, lightweight aggregate and boiler slag in restoration renders. Constr Build Mater 142:162-174. https://doi.org/10.1016/j. conbuildmat.2017.03.079

Correia JR, de Brito J, Pereira AS (2006) Effects on concrete durability of using recycled, ceramic aggregates. Mater Struct 39:169-177. https://doi.org/10.1617/s11527-005-9014-7

EN 197-1 Cement - part 1: composition, specifications and conformity criteria for common cements

EN 1015-11:2001P Methods of testing mortar for masonry Part 11: determining flexural strength and compressive strength of hardened mortar

EN 12370:2001 Methods of research of natural stone. Determination of resistance to crystallization of salts

EN 12012:2007 Methods of testing masonry. Determining resistance to freeze-thaw of ceramic masonry

EN 196-7:2008 Cement testing methods. Methods for collecting and preparing cement samples

EN 1936:2010 Natural stone test methods-determination of bulk density and density as well as total and open porosity

European Commission (2014) Towards a circular economy: a zero waste programme for Europe. 398 final. https://ec.europa.eu/envir onment/circular-economy/pdf/circular-economy-communication. pdf. Accessed 02 July 2014

Farinha CB, de Brito J, Veiga R (2015) Incorporation of fine sanitary ware aggregates in coating mortars. Constr Build Mater 83:194206. https://doi.org/10.1016/j.conbuildmat.2015.03.028

Frías M, Rodríguez O, Vegas I, Vigil R (2008) Properties of calcined clay waste and its influence on blended cement behavior. J Am Ceram Soc 91(4):1226-1230. https://doi.org/10.111 $1 / \mathrm{j} .1551-2916.2008 .02289 . x$

Gil D (2019) Synergy of the interaction of silica fly ash and microsilica on selected concrete properties. Dissertation. Lublin University of Technology, Lublin

Gonzalez-Corominas A, Etxeberria M (2014) Properties of high performance concrete made with recycled fine ceramic and coarse mixed aggregates. Constr Build Mater 68:618-626. https://doi. org/10.1016/j.conbuildmat.2014.07.016

Halicka A (2011) Ceramic sanitary ware waste as aggregate for concrete. Przegląd Budowlany 7-8:50-55 (in Polish)

Halicka A, Ogrodnik P, Zegardło B (2013) Using ceramic sanitary ware waste as concrete aggregate. Constr Build Mater 48:295-305. https://doi.org/10.1016/j.conbuildmat.2013.06.063

Higashiyama H, Yagishita F, Sano M, Takahashi O (2012) Compressive strength and resistance to chloride penetration of mortars using ceramic waste as fine aggregate. Constr Build Mater 26:96101. https://doi.org/10.1016/j.conbuildmat.2011.05.008 
Higashiyama H, Yamauchi K, Sappakittipakorn M, Sano M, Takahashi O (2013) A visual investigation on chloride ingress into ceramic waste aggregate mortars having different water to cement ratios. Constr Build Mater 40:1021-1028. https://doi.org/10.1016/j. conbuildmat.2012.11.078

Huseien GF, Mirza J, Ismail M, Ghoshal SK, Hussein AA (2017) Geopolymer mortars as sustainable repair material: a comprehensive review. Renew Sustain Energy Rev 80:54-74. https://doi. org/10.1016/j.rser.2017.05.076

Jackiewicz-Ręk W, Załęgowski K, Garbacz A, Bissonnette B (2015) Properties of cement mortars modified with ceramic waste fillers. Procedia Eng 108:681-687

Jimenez JR, Ayuso J, Lopez M, Fernandez JM, de Brito J (2013) Use of fine recycled aggregates from ceramic waste in masonry mortar manufacturing. Constr Build Mater 40:679-690. https://doi. org/10.1016/j.conbuildmat.2012.11.036

Karozou A, Stefanidou M (2018) Advances in clay-based mortars for protection against water penetration. Ceram Sci Eng 8:88. https ://doi.org/10.24294/cse.v0i0.598

Krzywobłocka-Laurów R (2000) Means for surface hydrophobization of concrete, ITB ZUAT-15/VI.11-1/00, Warszawa

Lucas J, de Brito J, Veiga R, Farinha CB (2016) The effect of using sanitary ware as aggregates on rendering mortars' performance. Mater Des 91:155-164. https://doi.org/10.1016/j.matde s.2015.11.086

Lugli S, Caroselli M, Marchetti SD, Vandelli V, Marzani G, Segattini R, Bianchic C, Weber J (2016) Building materials and degradation phenomena of the Finale Emilia Town Hall (Modena): an archaeometric study for the restoration project after the 2012 earthquake. Periodico di Mineralogia 85:59-67. https://doi.org/10.2451/2016P M371

Matias G, Faria P, Torres I (2014) Lime mortars with heat treated clays and ceramicwaste: a review. Constr Build Mater 73:125-136. https ://doi.org/10.1016/j.conbuildmat.2014.09.028

Medina C, SánchezdeRojas MI, Frías M (2012a) Reuse of sanitary ceramic wastes as coarse aggregate in eco-efficient concretes. Cement Concr Compos 34:48-54. https://doi.org/10.1016/j.cemco ncomp.2011.08.015

Medina C, Frías M, Sánchez de Rojas MI, Thomas C, Polanco JA (2012b) Gas permeability in concrete containing recycled ceramic sanitary ware aggregate. Constr Build Mater 37:597-605. https:// doi.org/10.1016/j.conbuildmat.2012.08.023

Medina C, Sánchez De Rojas MI, Frías M (2013) Properties of recycled ceramic aggregate concretes: water resistance. Cem Concr Compos 40:21-29. https://doi.org/10.1016/j.cemconcomp.2013.04.005

Mohammadhosseini H, Tahir MM (2018) Durability performance of concrete incorporating waste metalized plastic fibres and palm oil fuel ash. Constr Build Mater 180:92-102. https://doi. org/10.1016/j.conbuildmat.2018.05.282

Mohammadhosseini H, Yatim JM (2017) Microstructure and residual properties of green concrete composites incorporating waste carpet fibers and palm oil fuel ash at elevated temperatures. J Clean Prod 144:8-21. https://doi.org/10.1016/j.jclep ro.2016.12.168

Mohammadhosseini H, Yatim JM, Sam AM, Awal ASMA (2014) Durability performance of green concrete composites containing waste carpet fibers and palm oil fuel ash. J Clean Prod 144:448458. https://doi.org/10.1016/j.jclepro.2016.12.151

PN-B-04500:1985 Building mortars. Physical and endurance tests(in Polish)

PN-EN 932-2:2001 Methods of reducing laboratory samples

PN-EN 1097-6:2013-11 Tests for mechanical and physical properties of aggregates. Part 6: determination of grain density and water absorption

PN-EN 1367-1:2007 Tests of thermal properties and resistance of aggregates to weather conditions, part 1: determination of frost resistance

Puertas F, García I, Barba A, Gazulla MF, Palacios M, Gómez MP et al (2008) Ceramic wastes as alternative raw materials for Portland cement Clinker production. Cem Concr Compos 30(9):798-805. https://doi.org/10.1016/j.cemconcomp.2008.06.003

Siddique S, Shrivastava S, Chaudhary S (2017) Lateral force microscopic examination of interfacial transition zone in ceramic concrete. Constr Build Mater 155:688-725. https://doi.org/10.1016/j. conbuildmat.2017.08.080

Siddique S, Shrivastava S, Chaudhary S, Gupta T (2018) Strength and impact resistance properties of concrete containing fine bone china ceramic aggregate. Constr Build Mater 169:289-298. https ://doi.org/10.1016/j.conbuildmat.2018.02.213

Silva J, de Brito J, Veiga R (2008) Fine ceramics replacing cement in mortars partial replacement of cement with fine ceramics in rendering mortars. Mater Struct 41:1333-1344. https://doi. org/10.12691/ajcea-1-5-5

Stratoura M, Iaz DR, Badogiannis E (2018) Chloride penetration in lightweight aggregate mortars incorporating supplementary cementing materials. Adv Civ Eng 97:159-167. https://doi. org/10.1155/2018/9759167

Torkittikul P, Chaipanich A (2010) Utilization of ceramic waste as fine aggregate within Portland cement and fly ash concretes. Cem Concr Compos 32:440-449. https://doi.org/10.1016/j.cemco ncomp.2010.02.004

Urban J, Szeląg H (2014) Plaster mortar based on Roman cement, Patent Description (B1) 217096. Institute of Ceramics and Building Materials, Warsaw, Poland

Uzunow E (2014) Waste aggregates as an alternative for natural aggregates. Aggregates 4:36-39 (in Polish)

Publisher's Note Springer Nature remains neutral with regard to jurisdictional claims in published maps and institutional affiliations. 